\title{
The Flipped Classroom: A Survey of the Research
}

\section{Jacob Lowell Bishop, Utah State University}

Jacob Bishop holds B.S. and M.S. degrees in Mechanical Engineering. He is currently a graduate student at Utah State University pursuing a Ph.D. in Engineering Education. His research interests are multidisciplinary. In educational research, his interests include model-eliciting activities, open online education, educational data mining, and the flipped classroom. In quantitative methodology and psychometrics, his interests focus on the use of latent variable models to analyze variability and change over time.

\section{Dr. Matthew A Verleger, Embry-Riddle Aeronautical Univ., Daytona Beach}

Dr. Matthew Verleger is an assistant professor in Freshman Engineering at Embry-Riddle Aeronautical University. He has a B.S. in Computer Engineering, a M.S. in Agricultural \& Biological Engineering, and a Ph.D. in Engineering Education, all from Purdue University. Prior to joining the Embry-Riddle faculty, he spent two years as an assistant professor of Engineering Education at Utah State University. His research interests include Model-Eliciting Activities, online learning, and the development of software tools to facilitate student learning. 


\title{
The Flipped Classrom: A Survey of the Research
}

\begin{abstract}
Recent advances in technology and in ideology have unlocked entirely new directions for education research. Mounting pressure from increasing tuition costs and free, online course offerings is opening discussion and catalyzing change in the physical classroom. The flipped classroom is at the center of this discussion. The flipped classroom is a new pedagogical method, which employs asynchronous video lectures and practice problems as homework, and active, group-based problem solving activities in the classroom. It represents a unique combination of learning theories once thought to be incompatible - active, problem-based learning activities founded upon a constructivist ideology and instructional lectures derived from direct instruction methods founded upon behaviorist principles.

This paper provides a comprehensive survey of prior and ongoing research of the flipped classroom. Studies are characterized on several dimensions. Among others, these include the type of in-class and out-of-class activities, the measures used to evaluate the study, and methodological characteristics for each study. Results of this survey show that most studies conducted to date explore student perceptions and use single-group study designs. Reports of student perceptions of the flipped classroom are somewhat mixed, but are generally positive overall. Students tend to prefer in-person lectures to video lectures, but prefer interactive classroom activities over lectures. Anecdotal evidence suggests that student learning is improved for the flipped compared to traditional classroom. However, there is very little work investigating student learning outcomes objectively. We recommend for future work studies investigating of objective learning outcomes using controlled experimental or quasi-experimental designs. We also recommend that researchers carefully consider the theoretical framework used to guide the design of in-class activities.
\end{abstract}

\section{The Rise of the Flipped Classroom}

There are two related movements that are combining to change the face of education. The first of these is a technological movement. This technological movement has enabled the amplification and duplication of information at an extremely low-cost. It started with the printing press in the 1400 s, and has continued at an ever-increasing rate. The electronic telegraph came in the 1830s, wireless radio in the late 1800 s and early 1900 s, television in the 1920 s, computers in the 1940s, the internet in the 1960s, and the world-wide web in the 1990s.

As these technologies have been adopted, the ideas that have been spread through their channels have enabled a second movement. Whereas the technological movement sought to overcome real physical barriers to the free and open flow of information, this ideological movement seeks to remove the artificial, man-made barriers. This is epitomized in the free software movement (see, e.g., Stallman and Lessig ${ }^{[67]}$ ), although this movement is certainly not limited to software.

A good example of this can be seen from the encyclopedia. Encyclopedia Britannica has been 
continuously published for nearly 250 years ${ }^{[20]}$ (since 1768). Although Encyclopedia Britannica content has existed digitally since 1981, it was not until the advent of Wikipedia in 2001 that open access to encyclopedic content became available to users worldwide. Access to Encyclopedia Britannica remains restricted to a limited number of paid subscribers ${ }^{[21]}$, but access to Wikipedia is open, and the website receives over 2.7 billion US monthly page views ${ }^{[81]}$. Thus, although the technology and digital content was available to enable free access to encyclopedic content, ideological roadblocks prevented this from happening. It was not until these ideologies had been overcome that humanity was empowered to create what has become the world's largest, most up-to-date encyclopedia ${ }^{[81]}$.

In a similar way, we are beginning to see the combined effects of these two movements on higher education. In the technological arena, research has made significant advances. Studies show that video lectures (slightly) outperform in-person lectures ${ }^{[9]}$, with interactive online videos doing even better (Effect size $=0.5)^{[83,51]}$. Online homework is just as effective as paper-and-pencil homework $^{[8,27]}$, and carefully developed intelligent tutoring systems have been shown to be just as effective as human tutors ${ }^{[77]}$. Despite these advancements, adoption has been slow, as the development of good educational systems can be prohibitively expensive. However, the corresponding ideological movement is breaking down these financial barriers.

Ideologically, MIT took a significant step forward when it announced its OpenCourseWare (OCW) initiative in $2001^{[53]}$. This opened access to information that had previously only been available to students who paid university tuition, which is over $\$ 40,000 / \mathrm{yr}$ at $\mathrm{MIT}^{[54]}$. Continuing this trend, MIT alum Salman Khan founded the Khan Academy in 2006, which has released a library of over 3200 videos and 350 practice exercises 2012. The stated mission of the Khan Academy is to provide "a free world-class education to anyone anywhere2012." In the past year, this movement has rapidly gained momentum. Inspired by Khan's efforts, Stanford professors Sebastian Thrun and Andrew Ng opened access to their online courses in Fall 2011. Thrun taught artificial intelligence with Peter Norvig, attracting over 160,000 students to their free online course. Subsequently, Thrun left the university and founded Udacity, which is now hosting 11 free courses ${ }^{[76]}$. With support from Stanford, $\mathrm{Ng}$ also started his own open online educational initiative, Coursera. Princeton, the University of Pennsylvania, and the University of Michigan have joined the Coursera partnership, which has expanded its offerings to 42 courses $^{[10]}$. MIT has also upgraded its open educational initiative, and joined with Harvard in a $\$ 60$ million dollar venture, edX ${ }^{[19]}$. EdX will, "offer Harvard and MIT classes online for free."

While online education is improving, expanding, and becoming openly available for free, university tuition at brick-and-mortar schools is rapidly rising ${ }^{[56]}$. Tuition in the University of California system has nearly tripled since $2000^{[32]}$. Naturally, this is not being received well by university students in California ${ }^{[2]}$. Likewise, students in Quebec are actively protesting planned tuition hikes ${ }^{[13]}$. In resistance to planned tuition hikes, student protestors at Rutgers interrupted (on June 20,2012 ) a board meeting to make their voices heard ${ }^{[36]}$. Adding fuel to the fire, results from a recent study by Gillen et al. ${ }^{[31]}$ indicate that undergraduate student tuition is used to subsidize research. As a result, the natural question being asked by both students and educational institutions is exactly what students are getting for their money. This is applying a certain pressure on physical academic institutions to improve and enhance the in-person educational experience of their 
students.

Students are not the only ones demanding higher outcomes from educational institutions. There is also increasing pressure from accreditation institutions. In particular, the Accreditation Board for Engineering and Technology (ABET) specifies outcomes that university graduates in engineering and technology must meet for their programs to be accredited ${ }^{[1]}$. Commonly referred to as outcomes 3a-k, these criteria include, "an ability to communicate effectively," and "an ability to identify, formulate, and solve engineering problems," as well as, "an ability to function on multidisciplinary teams." Many of these criterion are generally difficult to teach and assess effectively with informative lectures and closed form questions.

Problem-based learning methods, however, can be much more effective at achieving these goals. Felder and Brent ${ }^{[22]}$ survey research indicating that problem-based learning methods can be used to fulfill ABET 3a-k outcomes. However, adoption of problem-based learning is hindered by the fact that the curriculum for engineering programs is already tightly packed. Cramming even more into these programs may seem impossible. Although computer technology is to blame for at least a portion of the uncomfortable situation in which educational institutions find themselves, it may also form a key part of the solution. Since the stone age, man has used tools to improve the effectiveness and efficiency of his efforts. In modern industry, this is accomplished by automating tasks that can be automated, and focusing human effort on those that cannot. Although group lectures have been sharply criticized in a portion of the educational literature, there seems to be little convincing evidence to support these criticisms. However, since video lectures are as effective as in-person lectures at conveying basic information ${ }^{[9,51,83]}$, the wisdom of using student and instructor time for live lectures is questionable. Rather, pre-recorded lectures can be assigned to students as homework, leaving class time open for interactive learning activities-activities that cannot be automated or computerized. This is the key concept behind what is becoming the new buzzword in educational circles: the flipped classroom.

\section{Buzz About the Flipped Classroom}

There is a considerable amount of buzz in academic circles at all levels, focused around the flipped classroom. These appear mainly as newspaper articles (particularly academically-oriented ones) and online blogs. For a preliminary index into these, we have provided an list of 39 unique blog posts or online news articles, which is given in a dedicated references section following the main bibliography in this article. In addition to news articles and blog posts, there are also complete websites starting to pop up, dedicated to promoting the flipped classroom ideology. Links to these websites are given following the news articles and blog posts references section.

The online buzz is not only limited to promotional websites and informational articles. Several organizations are beginning to market materials to help instructors who want to implement the flipped model in their classroom. The main focus of these is to provide resources for making screencasts and Khan Academy-style ${ }^{[46]}$ instructional videos ${ }^{* 1,2,3,6^{*}}$. However, one ${ }^{* *}$ is even even offering certifications ${ }^{*} 5^{*}$ (and a t-shirt) for "Certified" flipped classroom instructors. 
Table 1: Restricted definition of the flipped classroom.

\begin{tabular}{ccc} 
Style & Inside Class & Outside Class \\
\hline Traditional & Lectures & Practice Exercises \& Problem Solving \\
Flipped & Practice Exercises \& Problem Solving & Video Lectures \\
\hline
\end{tabular}

Table 2: Broader definition of the de-facto flipped classroom. Inside Class Outside Class

Questions \& Answers $\quad$ Video Lectures

Group-Based/Open-Ended Problem Solving Closed-Ended Quizzes \& Practice Exercises

\section{Defining the Flipped Classroom}

Despite the buzz around the flipped classroom as an exciting new topic in educational research, there is a lack of consensus on what exactly the flipped classroom is, and there is also a limited amount of scholarly research on its effectiveness. First, we will attempt to define the flipped classroom. Perhaps the simplest definition of the flipped, (or inverted) classroom is given by Lage et al. ${ }^{[49]}$. "Inverting the classroom means that events that have traditionally taken place inside the classroom now take place outside the classroom and vice versa" (p.32). This flipping is demonstrated ${ }^{1}$ in Table 1 . While this explanation captures the rationale for using the terminology inverted or flipped, it does not adequately represent the practice of what researchers are calling the flipped classroom. This definition would imply that the flipped classroom merely represents a re-ordering of classroom and at-home activities. In practice, however, this is not the case $^{[49,24,14,74,80,82]}$.

Most research on the flipped classroom employs group-based interactive learning activities inside the classroom, citing student-centered learning theories based on the works of Piaget 1967 and Vygotsky ${ }^{[79]}$. The exact nature of these activities varies widely between studies. Similarly, there is wide variation in what is being assigned as "homework". The flipped classroom label is most often assigned to courses that use activities made up of asynchronous web-based video lectures and closed-ended problems or quizzes. In many traditional courses, this represents all the instruction students ever get. Thus, the flipped classroom actually represents an expansion of the curriculum, rather than a mere re-arrangement of activities. A simplified depiction of this is shown in Table 2.

We define the flipped classroom as an educational technique that consists of two parts: interactive group learning activities inside the classroom, and direct computer-based individual instruction outside the classroom. A graphic representation of this definition is shown in Figure 1. We restrict this definition to exclude designs that do not employ videos as an outside of the classroom activity. While a broad conception of the flipped classroom may be useful, definitions that become too broad suggest that assigning reading outside of class and having discussions in class constitutes the flipped classroom. We reject these definitions ${ }^{2}$. 


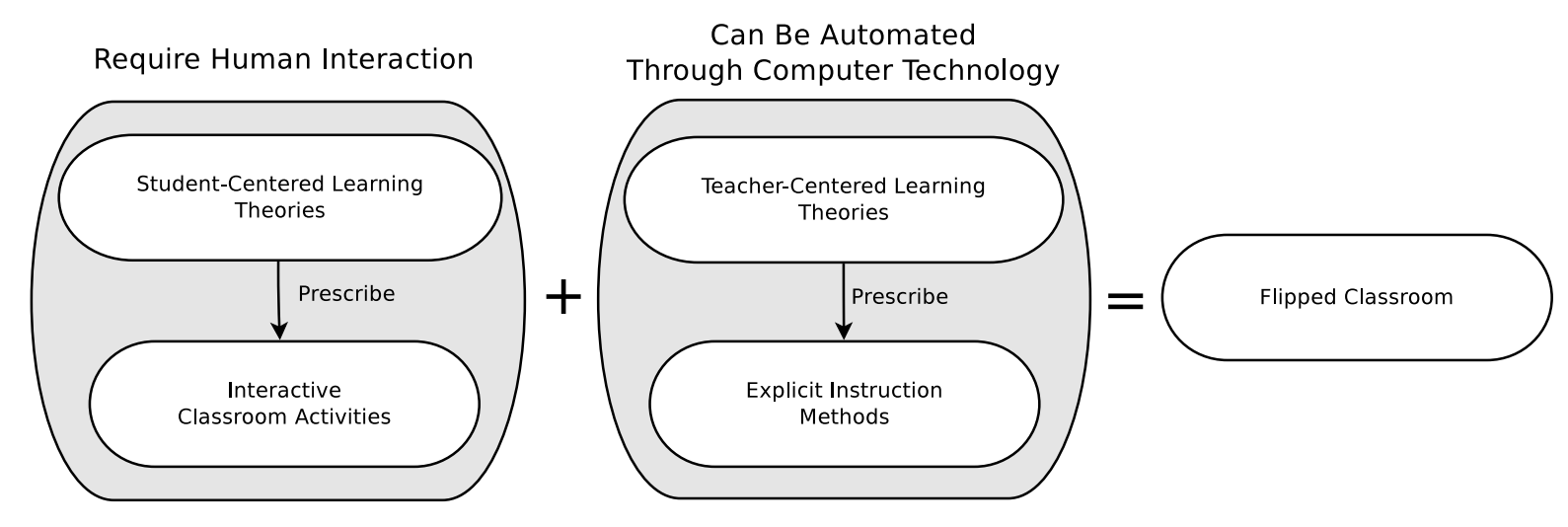

Figure 1: Flipped Classroom.

\section{Theoretical Frameworks for the Flipped Classroom}

Now that we have a working definition of the flipped classroom, we are ready to discuss the theoretical frameworks used to guide the design of in-class activities. The theoretical foundations used for justifying the flipped classroom typically focus on reasons for not using classroom time to deliver lectures. These stem from a large body of literature on student-centered learning, which looks primarily to the theories of Piaget 1967 and Vygotsky 1978. Tudge and Winterhoff ${ }^{[75]}$ provide a detailed analysis of the similarities and differences between these two theories. Foot and Howe ${ }^{[25]}$ provide the background outlining connections leading to peer-assisted learning. In particular, they point out that constructivism and collaborative learning stem from Piaget's theory of cognitive conflict, and that cooperative learning stems from Vygotsky's zone of proximal development. Topping and Ehly ${ }^{[73]}$ indicate that peer-assisted learning is an umbrella large enough to accommodate both of these theories. Smith and MacGregor ${ }^{[66]}$ claim that Lewin ${ }^{[50]}$ and Deutsch ${ }^{[15]}$ were important influences in cooperative learning through their social interdependence theories. Constructivism is considered the source for the theories problem-based and active learning ${ }^{[34]}$. Kolb's theory of experiential learning draws from Piaget, Dewey, and Lewin. This then forms the basis of Kolb's learning styles. Felder-Silverman 1988 learning styles draw both from Kolb's theory of learning styles and from Jung's theory of psychological types. Adapted and expanded from an initial diagram by Verleger ${ }^{[78]}$, Figure 2 is useful in tracing the progression and developmental relationship of different student-centered learning theories present in the literature.

In addition to the relationship between these theories due to historical development, it is also possible to generate a Venn-diagram to show the complex relationship between these groups of theories, shown in Figure 3. It is important to note that while learning styles serves as a justification for differentiated learning activities, it does not necessarily provide a framework for how these activities should be structured. This is why learning styles does not appear in Figure 3. A brief overview of these student-centered learning theories and relevant literature is provided in the following (sub)sections. 


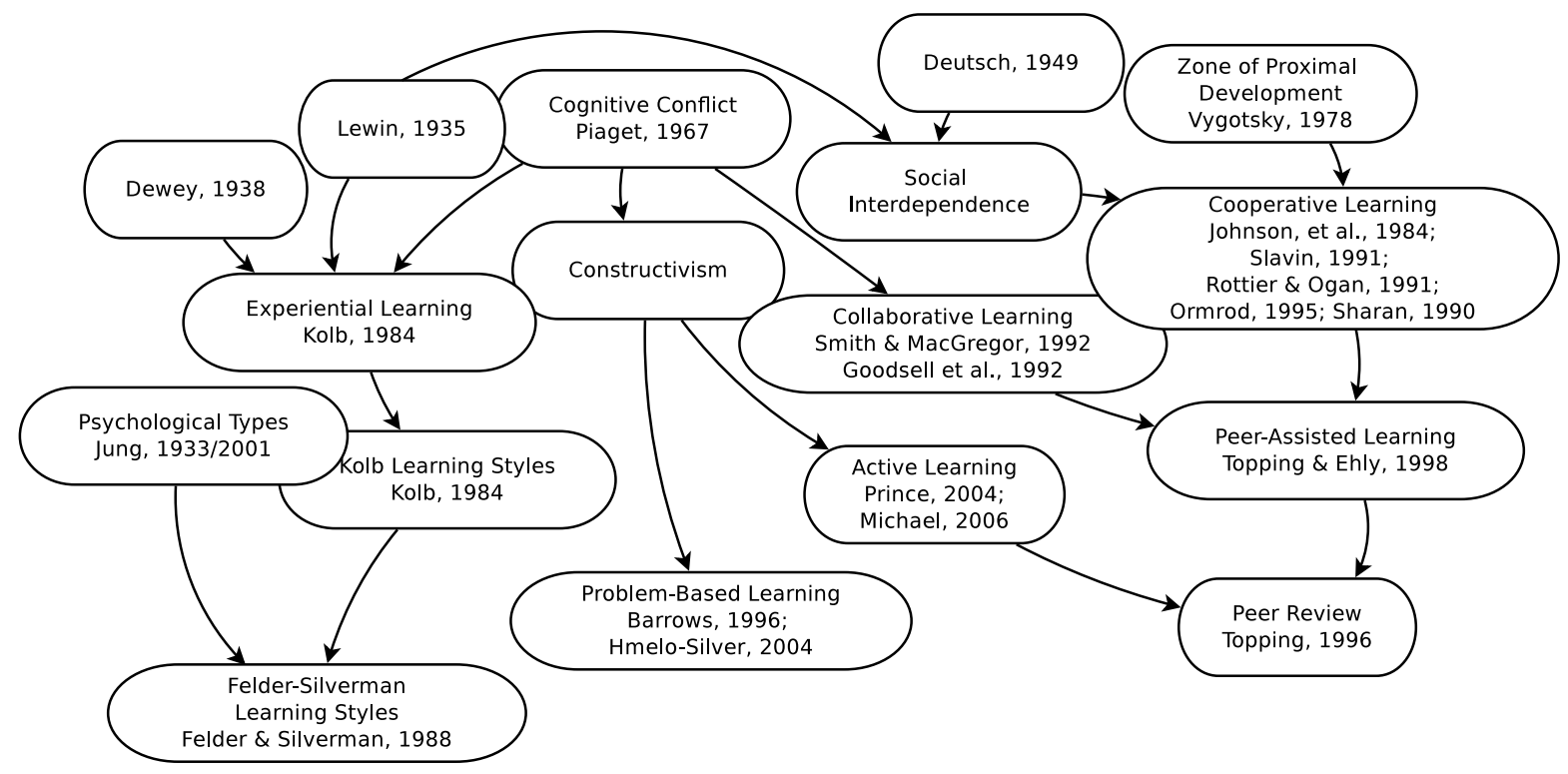

Figure 2: Psycho-Educational Origins of Student-Centered Learning Theories

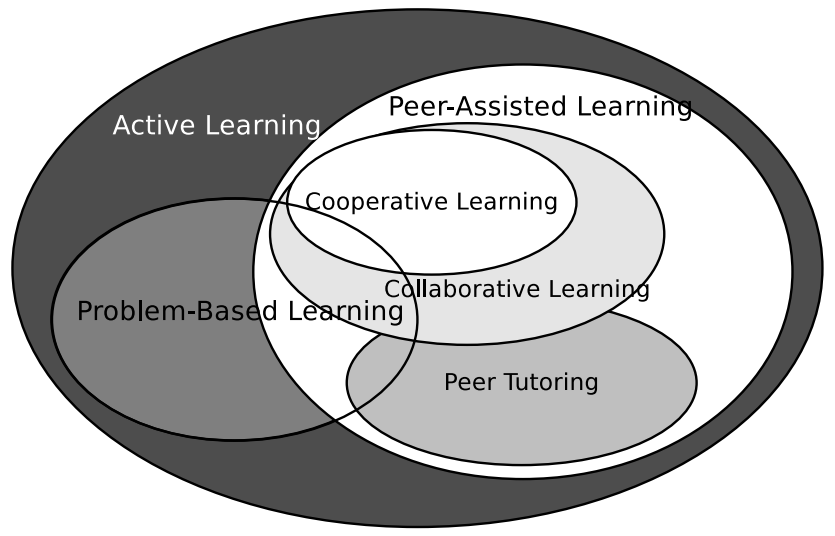

Figure 3: Venn diagram of several student-centered learning theories and methods. 


\subsection{Learning Styles}

Learning styles theories posit that individuals have unique learning styles, and that matching learning experiences with particular learning styles improves educational outcomes. There are several strands within the learning styles literature, but extensive exploration of all of these is beyond the scope of the current work. We discuss only two. Depicted in Figure 2 are the origins of the Kolb ${ }^{[47]}$ learning style. Kolb identifies Lewin, Dewey, and Piaget as the sources from which he derives his theory of experiential learning. Kolb's own model of learning styles is then based upon this theory. This model consists of a universal learning cycle and two embedded dimensions, perception and processing. Kolb's four learning styles are given by the permutations of these two dimensions.

The learning styles theory of Felder and Silverman ${ }^{[23]}$ is also noteworthy, as this was developed specifically for use in engineering education. Felder and Silverman identify at least two sources for the dimensions of their model, including Jung's ${ }^{[42]}$ (1933) theory of psychological types and Kolb's learning styles. This model consists of five dimensions, with two extremes for each dimension - the permutation yields 32 learning styles. These dimensions include perception, input, organization, processing, and understanding. Corresponding categories for teaching styles are established along the dimensions of content, presentation, organization, student participation, and perspective.

\subsection{Peer-Assisted, Collaborative, and Cooperative Learning}

Topping and Ehly ${ }^{[73]}$ define peer assisted learning as, "the acquisition of knowledge and skill through active helping and supporting among status equals or matched companions" (p.1). This broad definition prepares us for the statement by Foot and Howe ${ }^{[25]}$, "Taken together, the processes [collaborative learning and peer tutoring] describe and seek to explain underpin virtually all the [peer-assisted learning] techniques currently in educational practice" (p.28). Smith and MacGregor ${ }^{[66]}$ further explain, "cooperative learning represents the most carefully structured end of the collaborative learning continuum" (p.15). Thus, while Figure 2 is useful for tracing the origins and influences of peer-assisted learning, it does not adequately represent the relationship of this with other closely-related learning theories. Rather, the preceding statements lead to a relationship akin to the one given in Figure 3.

\subsection{Cooperative Learning}

Foot and Howe ${ }^{[25]}$ describe cooperative learning as including three key parts: 1) Students work in teams toward the attainment of some superordinate goal. 2) Labor is divided between team members, such that each individual takes responsibility for a different sub-goal. 3) Individual contributions are pooled into a composite product to ensure that the goal is reached.

Synthesizing the views of several theorists ${ }^{[38,64,62,57]}$, Doolittle ${ }^{[18]}$ notes that while there is not perfect consensus on what constitutes cooperative learning, five factors are paramount: 1) Positive interdependence, 2) Face-to-face interaction, 3) Individual accountability, 4) Small group \& interpersonal skills, 5) Group self-evaluation. 
A Meta-analysis of the effects of cooperative learning methods are given by Slavin ${ }^{[65]}$, Johnson et al. ${ }^{[40]}$, and Johnson et al. ${ }^{[41]}$. Of these, Johnson et al. ${ }^{[41]}$ provide the most detail, ranking specific cooperative learning methods by effectiveness. These have broad variation. The magnitude of effect sizes range from low (0.18) to high (0.85). The most effective of these is Learning Together \& Alone, which focuses on, "the integrated use of cooperative, competitive and individualistic learning" [39]. In a more recent publication, Johnson and Johnson ${ }^{[39]}$ give a dedicated meta-analysis of this particular cooperative learning method.

\subsection{Problem-Based Learning}

Hmelo-Silver ${ }^{[37]}$ lays out five goals of problem-based learning. These include helping students develop 1) Flexible knowledge, 2) Effective problem-solving skills, 3) Self-directed learning skills, 4) Effective collaboration skills, and 5) intrinsic motivation.

Barrows $^{[4]}$ describes six characteristics of problem-based learning, running somewhat parallel to these goals: 1) Learning is Student-Centered. 2) Learning Occurs in Small Student Groups.

3) Teachers are Facilitators or Guides. 4) Problems Form the Organizing Focus and Stimulus for Learning. 5) Problems are a vehicle for the development of clinical problem-solving skills. 6) New information is acquired through self-directed learning.

Dochy et al. ${ }^{[16]}$ and Gijbels et al. ${ }^{[30]}$ both present meta-analytic results on the effectiveness of problem-based learning (PBL). These indicate that the effect of PBL on skills is positive, while its effect on knowledge is negative. Combined results indicate an overall negative effect for problembased learning. Gijbels et al. ${ }^{[30]}$ recommend careful consideration of assessment methods in measuring problem-based learning outcomes.

\subsection{Active Learning}

Prince $^{[61]}$ defines active learning broadly as, "any instructional method that engages students in the learning process." This definition is itself broad enough to include many traditional classroom activities such as lectures (provided students are reflecting, taking notes, or asking questions). However, in an effort to maintain contrast with traditional teacher-centered ${ }^{3}$ approaches, these methods are systematically dismissed by explicit exclusion. Thus, active learning acts as a superset for both peer-assisted and problem-based learning approaches. Prince also clarifies the relationship between these two, indicating that problem-based learning is, "always active and usually (but not necessarily) collaborative or cooperative." This leads to a revision of the previous diagram, resulting in the relationship shown in Figure 3. The reviews of Prince ${ }^{[61]}$ and Michael ${ }^{[52]}$ provide a broad sweep of the literature, highlighting evidence for active learning.

The importance of these (student-centered) learning theories to the flipped classroom cannot be understated. Without these, the flipped classroom simply does not exist. As shown in Figure 1, the flipped classroom is made up of two components: one component that requires human interaction (in-class activities), and a second component that is automated through the use of computer technologies such as video lectures (outside activities). Obviously, the classroom component is critical, and the student-centered learning theories just presented provide the philosophical basis for the design of these activities. Unfortunately, some may overlook this fact and instead 
conceptualize the flipped classroom based only on the presence (or absence) of computer technology such as video lectures. This would be a mistake, since the pedagogical theory used to design the in-class experience may ultimately be the determining factor in the success (or failure) of the flipped classroom.

\section{Research on the Flipped Classroom}

A search of the literature through June 2012 revealed 24 studies related to the flipped classroom. A spreadsheet with a complete encoding of study features was created, including the publication type, year of publication, course, educational institution, study type, sample size, measurement instruments, theoretical framework, in-class activities, and out-of-class activities. A limited subset of this information is listed in Table 3.

The combination of in-class and out-of-class activities was evaluated to determine whether the study actually represented a flipped classroom. To meet the criterion, out-of-class activities must include required video lectures; in-class activities must be required, and must involve interactive learning activities - specifically, the primary in-class component could not be lectures. This eliminated eleven studies. Some of these required students to read material before class, rather than having it presented in an audiovisual format (e.g., Papadopoulos et al. ${ }^{[58]}$, Papdopoulos and Santiago-Román ${ }^{[59]}$, others maintained that either video lectures or in-class activities were optional (e.g., Thomas and Philpot ${ }^{[72]}$ ). Of the remaining studies, all but two either formally or informally examined student perceptions.

Despite differences among studies, general reports of student perceptions were relatively consistent. Opinions tended to be positive, but there were invariably a few students who strongly disliked the change. Students did tend to watch the videos when assigned, and even when they were not. DeGrazia et al. ${ }^{[12]}$ notes that students supplied with optional video lectures came to class much better prepared than when they had been given textbook readings. This observation is encouraging because although learning gains are high for information presented textually, Sappington et al. ${ }^{[63]}$ shows that college students don't generally complete reading assignments. Nevertheless, upon recommendation by students, many instructors instituted a required pre-class quiz on the lecture material. This was touted as a highly successful practice. Students preferred live in-person lectures to video lectures, but also liked interactive class time more than in-person lectures $^{[74]}$. Shorter, rather than longer videos were preferred ${ }^{[82]}$.

The two remaining results that both qualified as flipped classroom studies and examined student performance are those by Moravec et al. ${ }^{[55]}$ and Day and Foley ${ }^{[11]}$. Moravec et al. ${ }^{[55]}$ modified the presentation method for three lectures in an introductory biology course. Students were required to watch narrated PowerPoint videos and complete a worksheet before class time. In class, students participated in alternating ten-minute mini-lectures and five to seven minute active learning exercises. This led to a performance increase of $21 \%$ on exam questions related to the topics introduced outside class with videos. While these results are encouraging, there are several shortcomings to this study. First, in-class activities still carried a lecture component, even though time was provided for interactive activities. Second, the duration of the treatment was very short, and topics on both sides of the flipped topics were still taught with traditional methods. This leaves 
Table 3: Published Studies of the Flipped Classroom

\begin{tabular}{|c|c|c|c|c|c|c|c|}
\hline $\begin{array}{l}\text { Study Class, } \\
\text { Primary Author }\end{array}$ & $\begin{array}{l}\text { Grade } \\
\text { Level }\end{array}$ & $\begin{array}{l}\text { In-Class } \\
\text { Activities }\end{array}$ & $\begin{array}{c}\text { Out-of-Class } \\
\text { Activities }\end{array}$ & $\begin{array}{c}N, \\
\text { Treatment }\end{array}$ & $\begin{array}{c}N, \\
\text { Control }\end{array}$ & $\begin{array}{l}\text { Instrument } \\
\text { Type }\end{array}$ & $\begin{array}{c}\text { Test } \\
\text { Structure }\end{array}$ \\
\hline \multicolumn{8}{|l|}{ Full Flip, Single-Group } \\
\hline Lage $^{[48,49]}$ & $\mathrm{Fr}$ & SGA & VL & 40 & - & $\mathrm{O}$ & $\mathrm{O}-\mathrm{X}$ \\
\hline Kaner $^{[44]}$ & $\mathrm{U}$ & SGA & VL & - & - & $\mathrm{O}$ & $\mathrm{O}-\mathrm{X}$ \\
\hline Bergmann $^{[5,6]}$ & HS & - & - & - & - & - & - \\
\hline Talbert $^{[70]}$ & $\mathrm{U}$ & $\mathrm{SGA} ; \mathrm{Q}$ & VL & 7 & - & $\mathrm{O}$ & $\mathrm{O}-\mathrm{X}$ \\
\hline Gannod $^{[28,29]}$ & $\mathrm{Fr}-\mathrm{Gr}$ & HW;SGA & VL & 20;160 IP & - & $\mathrm{O}$ & $X-X$ \\
\hline Toto $^{[74]}$ & $\mathrm{Jr}$ & - & $\mathrm{VL} ; \mathrm{Q}$ & 74 & - & $\mathrm{O}$ & $\mathrm{X}_{1}-\mathrm{X}_{2}$ \\
\hline Zappe $^{[82]}$ & $\mathrm{U}$ & SGA & $\mathrm{VL} ; \mathrm{Q}$ & 77 & - & $\mathrm{O}$ & $-X X$ \\
\hline Demetry $^{[14]}$ & $\mathrm{U}$ & SGA & $\mathrm{VL} ; \mathrm{Q}$ & 125 & - & - & - \\
\hline \multicolumn{8}{|l|}{ Full Flip, Controlled } \\
\hline Day $^{[11]}$ & So-Gr & SGA & VL;HW & 28 & 18 & $\mathrm{O} ; \mathrm{P}$ & $\mathrm{O}-\mathrm{X}$ \\
\hline Foertsch $^{[24]}$ & So-Jr & SGA & VL & 415 & 234 & $\mathrm{O}$ & $\mathrm{O}-\mathrm{X}$ \\
\hline \multicolumn{8}{|l|}{ Partial Flip, Single-Group } \\
\hline Kellogg $[45]$ & $\mathrm{U}$ & - & $\mathrm{CM}$ & - & - & - & - \\
\hline Warter-Perez ${ }^{[80]}$ & Fr-So & L;SGA & VL & $25-30$ & - & $\mathrm{O}$ & $X-X$ \\
\hline Dollar ${ }^{[17]}$ & $\mathrm{U}$ & SGA & $\mathrm{CM}$ & - & - & $\mathrm{P}$ & $X-X$ \\
\hline $\operatorname{Tan}^{[71]}$ & $\mathrm{Fr}$ & $\mathrm{L} ; \mathrm{VL}$ & HW? & 75 & - & $\mathrm{O}$ & $\mathrm{O}-\mathrm{X}$ \\
\hline Baker $^{[3]}$ & $\mathrm{U}$ & SGA & $\mathrm{RA} ; \mathrm{CM}$ & - & - & - & $\mathrm{O}-\mathrm{X}$ \\
\hline Bland $^{[7]}$ & So-Jr & HW & HW & - & - & $\mathrm{O}$ & $\mathrm{O}-\mathrm{X}$ \\
\hline Franciszkowicz $^{[26]}$ & Fr-So & HW & HW & 1074 & - & $\mathrm{O}$ & $-\mathrm{XX}$ \\
\hline \multicolumn{8}{|l|}{ Partial Flip, Controlled } \\
\hline Thomas $^{[72]}$ & $\mathrm{U}$ & HW & VL & 405 & $275-668$ & $\mathrm{P}$ & $\mathrm{O}-\mathrm{X}$ \\
\hline Stelzer ${ }^{[68]}$ & $\mathrm{U}$ & L;SGA & $\mathrm{VL} ; \mathrm{CM}$ & $500+$ & $500+$ & $\mathrm{O} ; \mathrm{P}$ & $\mathrm{O}-\mathrm{X}$ \\
\hline Moravec $^{[55]}$ & Fr-So & L;SGA & VL & 795 & 1310 & $\mathrm{O} ; \mathrm{P}$ & $\mathrm{O}-\mathrm{X}$ \\
\hline Strayer ${ }^{[69]}$ & $\mathrm{U}$ & SGA & $\mathrm{CM}$ & 23 & 26 & $\mathrm{O}$ & $\mathrm{O}-\mathrm{X}$ \\
\hline Papadopoulos $[58,59]$ & $\mathrm{U}$ & $\mathrm{L} ?$ & $\mathrm{CM} ; \mathrm{HW}$ & 43 & 11 & $\mathrm{O} ; \mathrm{P}$ & $X-X$ \\
\hline
\end{tabular}

Note. Grade Level: $\mathrm{U}=$ Undergraduate; $\mathrm{Fr}, \mathrm{So}, \mathrm{Jr}, \mathrm{Sr}=$ First, Second, Third, and Fourth Year Undergraduate; HS = High School. In-Class and Out-of-Class Activities: $\mathrm{L}=$ Lecture; VL = Video Lecture; HW = Homework; Q = Quizzes; SGA $=$ Small-Group Activities; $\mathrm{CM}=$ Computer Modules (text-based). Number of Participants: IP $=$ In Progress. Instrument Type: $\mathrm{O}=$ Subjective Opinion Survey or Informal Assessment; $\mathrm{P}=$ Objective Performance Test. Test Structure: $\mathrm{O}-\mathrm{X}=$ Post-Test Only; $\mathrm{X}-\mathrm{X}=$ Matched Pretest-Posttest; $X_{1}-X_{2}=$ Unmatched Pre- and Post Measures; $-\mathrm{XX}=$ Mid- and Post- Semester Measures. Information for entries marked with - was missing or not available. 
open the question of whether similar results would be achieved across all topics if the entire class were flipped.

Day and Foley ${ }^{[11]}$ conducted their study in a senior-level computer interaction course. They taught concurrent experimental and comparison sections of the course, and matched sections on topics, assignments, and time on task. Students in the experimental section watched narrated PowerPoint videos outside of class, and participated in interactive learning activities inside class. Students in the flipped environment scored significantly higher on all homework assignments, projects, and tests.

In summary, of all the studies on the flipped classroom, there is only one (Day and Foley ${ }^{[11]}$ ) that has examined student performance throughout a semester. While the results from this study are encouraging, this is not sufficient evidence to warrant generalization far beyond that situation. Further, the solution was very specific, rather than being based on established principles to guide adaptation. Thus, additional research is needed to examine the influence of flipped classroom instruction on objective learning outcomes.

\section{Future Directions for Research on the Flipped Classroom}

We suggest that in order to ensure progress, future research on the flipped classroom should employ controlled studies that objectively examine student performance throughout a semester, with both traditional and concept-inventory ${ }^{[35]}$ style problems. Further, we recommend that researchers employing the flipped classroom leverage the existing research and theoretical frameworks to guide their use and design of in-class activities. As a side-note, we recommend that researchers clearly describe the activities used for both in-class and out-of-class activities (this was not always clear for studies we examined). The affordable state of recording technology and ubiquity web-based dissemination tools make research on the flipped classroom both timely and cost-effective.

\section{References}

To improve readability, the references for this paper are divided into five distinct sections. Endnotes are denoted without delimiters. The main article references are numbered inside square brackets, while articles and blog posts promoting or discussing the flipped classroom are marked with parenthesis. Complete websites dedicated to the flipped classroom are denoted with dashes, and web resources for flipped classroom teachers are separated with asterisks.

\section{References: Notes}

1 Note that there are two other possible permutations of lecture and homework. Both may take place in class, or both may take place outside class. These might be referred to as boarding school and independent study, respectively.

2 We reject these definitions for two reasons. First, if too liberal a definition is used, it becomes impossible to evaluate the effectiveness of the flipped classroom. Second, students tend not to complete assigned readings. 
Thus, the effectiveness of such a method will not tend to match our definition.

3 The label student-centered is carefully crafted for linguistic effect. This is much like the label pro-choice, which is crafted to portray an opposite of anti-choice or pro-slavery. Correspondingly, the label pro-life suggests an opposite of pro-death or anti-life. Educators do not typically self-identify as having a teachercentered or non-student focused teaching philosophy. Like its political counterpart, the educational debate is both complex and highly polarizing.

\section{References: Research on the Flipped Classrom}

[1] Accreditation Board for Engineering and Technology. Criteria for accrediting engineering programs effective for evaluations during the 2010-2011 accreditation cycle, 2009.

[2] Nanette Asimov. Protests as UC regents seek to avoid tuition hike. San Francisco Chronicle, May 2012. URL http://www . sfgate.com/education/article/Protests-as-UC-regents-seek-to-avoidtuition-hike-3564366.php.

[3] J. Baker. The "classroom flip": Using web course management tools to become the guide on the side. In 11th International Conference on College Teaching and Learning, 2000.

[4] H.S. Barrows. Problem-based learning in medicine and beyond: A brief overview. New Directions for Teaching and Learning, 1996(68):3-12, 1996.

[5] J. Bergmann and A. Sams. Remixing chemistry class: Two colorado teachers make vodcasts of their lectures to free up class time for hands-on activities. Learning \& Leading with Technology, 36(4):22-27, 2009.

[6] J. Bergmann and A. Sams. Flip Your Classroom: Talk to Every Student in Every Class Every Day. International Society for Technology in Education, 2012. ISBN 9781564843159. URL http://books . google. com/books?id=nBi2pwAACAAJ.

[7] L. Bland. Applying flip/inverted classroom model in electrical engineering to establish life-long learning. In Proceedings of the ASEE Annual Conference \& Exposition. Chicago, Illinois., 2006.

[8] S.W. Bonham, D.L. Deardorff, and R.J. Beichner. Comparison of student performance using web and paperbased homework in college-level physics. Journal of Research in Science Teaching, 40(10):1050-1071, 2003.

[9] P.A. Cohen, B.J. Ebeling, and J.A. Kulik. A meta-analysis of outcome studies of visual-based instruction. Educational Technology Research and Development, 29(1):26-36, 1981.

[10] Coursera. Courses for everyone, 2012. URL https://www . coursera.org/.

[11] J. A. Day and J. D. Foley. Evaluating a web lecture intervention in a human-computer interaction course. IEEE Transactions on Education, 49(4):420-431, 2006.

[12] Janet L. DeGrazia, John L. Falconer, Garret Nicodemus, and Will Medlin. Incorporating screencasts into chemical engineering courses. In Proceedings of the ASEE Annual Conference \& Exposition, 2012.

[13] Jacqueline Delange. Quebec student protests: Tuition protests planned for Montreal and Quebec City. Huffington Post, June 2012. URL http://www. huffingtonpost.ca/2012/06/22/quebec-studentprotests_n_1617840.html.

[14] C. Demetry. Work in progress: An innovation merging "classroom flip" and team-based learning. In Proceedings, 40th ASEE/IEEE Frontiers in Education Conference, 2010.

[15] Morton Deutsch. A theory of cooperation and competition. Human relations, 2(2):129-152, 1949. doi: $10.1177 / 001872674900200204$.

[16] F. Dochy, M. Segers, P. Van den Bossche, and D. Gijbels. Effects of problem-based learning: A meta-analysis. Learning and instruction, 13(5):533-568, 2003.

[17] A. Dollar. A web-based statistics course used in an inverted classroom. In Proceedings of the ASEE Annual Conference \& Exposition, 2009.

[18] P.E. Doolittle. Understanding cooperative learning through Vygotsky. In Lily National Conference on Excellence in College Teaching, Colombia, SC, June 2-4 1995.

[19] edX, 2012. URL http://www.edxonline.org/release.html.

[20] Encyclopaedia Britannica. Encyclopaedia Britannica, 2012. URL http://www.britannica.com/ 
EBchecked/topic/186618/Encyclopaedia-Britannica.

[21] Encyclopaedia Britannica. Encyclopaedia Britannica, 2012. URL http://store.britannica.com/.

[22] R.M. Felder and R. Brent. Designing and teaching courses to satisfy the ABET engineering criteria. Journal of Engineering Education, 92(1):7-25, 2003. ISSN 1069-4730.

[23] R.M. Felder and L.K. Silverman. Learning and teaching styles in engineering education. Engineering education, 78(7):674-681, 1988.

[24] J. Foertsch, G. Moses, J. Strikwerda, and M. Litzkow. Reversing the lecture/homework paradigm using eteach $\AA$ web-based streaming video software. Journal of Engeneering Education-Washington, 91(3):267274, 2002.

[25] H. Foot and C. Howe. The psychoeducational basis of peer-assisted learning. In K.J. Topping and S.W. Ehly, editors, Peer-Assisted Learning, pages 27-43. Lawrence Erlbaum Associates, 1998.

[26] M. Franciszkowicz. Video-based instruction to enhance an active learning environment for general chemistry. Journal of the Research Center for Educational Technology, 4(2):5-14, 2008.

[27] H. Fynewever. A comparison of the effectiveness of web-based and paper-based homework for general chemistry. The Chemical Educator, 13(4):264-269, 2008.

[28] G.C. Gannod. WIP: Using podcasting in an inverted classroom. In Proceedings of the 37th IEEE Frontiers in Education Conference, 2007.

[29] G.C. Gannod, J.E. Burge, and M.T. Helmick. Using the inverted classroom to teach software engineering. In Proceedings of the 30th international conference on Software engineering, pages 777-786. ACM, 2008.

[30] D. Gijbels, F. Dochy, P. Van den Bossche, and M. Segers. Effects of problem-based learning: A meta-analysis from the angle of assessment. Review of educational research, 75(1):27-61, 2005.

[31] Andrew Gillen, Matthew Denhart, and Jonathan Robe. Who subsidizes whom? An analysis of educational costs and revenues. Policy paper, Center for College Affordability and Productivity, 2011.

[32] Jennifer Gollan. Tuition hyperinflation. The Bay Citizen, July 2011. URL http://www . baycitizen. org/ education/story/tuition-hyperinflation/.

[33] A.M. Goodsell, M. Maher, and V. Tinto, editors. Collaborative learning: A sourcebook for higher education. National Center on Postsecondary Teaching, Learning and Assessment, 1992.

[34] R.S. Grabinger and J.C. Dunlap. Rich environments for active learning: A definition. Association for Learning Technology Journal, 3(2):5-34, 1995.

[35] D. Hestenes, M. Wells, and G. Swackhamer. Force concept inventory. The physics teacher, 30(3):141-158, 1992.

[36] Kelly Heyboer. Long Rutgers board meeting ends with short protest over tuition costs and restructuring plan. nj.com, June 2012. URL http://www.nj.com/news/index.ssf/2012/06/long_rutgers_board_ meeting_end.html.

[37] C.E. Hmelo-Silver. Problem-based learning: What and how do students learn? Educational Psychology Review, 16(3):235-266, 2004.

[38] D.W. Johnson. Circles of learning: Cooperation in the classroom. Association for supervision and curriculum development, Alexandria, VA, 1984.

[39] D.W. Johnson and R.T. Johnson. Learning together and alone: Overview and meta-analysis. Asia Pacific Journal of Education, 22(1):95-105, 2002.

[40] D.W. Johnson, R.T. Johnson, and K.A. Smith. Cooperative learning returns to college what evidence is there that it works? Change: The Magazine of Higher Learning, 30(4):26-35, 1998.

[41] DW Johnson, RT Johnson, and MB Stanne. Cooperative learning methods: A meta-analysis. Methods, 1: 1-33, 2000.

[42] Carl G. Jung. Modern man in search of a soul. Psychology Press, 2001. (C. F. Baynes, Trans. Original work published 1933).

[43] S. Kadel and J.A. Keehner, editors. Collaborative Learning: A Sourcebook for Higher Education, Vol. 2. National Center on Postsecondary Teaching, Learning, and Assessment, University Park, PA, 1994. 
[44] C. Kaner and R. Fiedler. Inside out: A computer science course gets a makeover. In Association for Educational Communication and Technology International Conference, 2005.

[45] S. Kellogg. Technology enabled support modules for the inverted entrepreneurial classroom. In Proceedings of the ASEE Annual Conference \& Exposition. Pittsburgh, Pennsylvania, 2008.

[46] Khan Academy. Watch. practice. learn almost anything for free., 2012. URL http://www . khanacademy . org/about.

[47] David A. Kolb. Experiential learning: Experience as the source of learning and development, volume 1. Prentice-Hall Englewood Cliffs, NJ, 1984. ISBN 9780132952613. URL http://books.google.com/ books?id=ufnuAAAAMAAJ.

[48] M.J. Lage and G. Platt. The internet and the inverted classroom. The Journal of Economic Education, 31(1): 11, 2000.

[49] M.J. Lage, G.J. Platt, and M. Treglia. Inverting the classroom: A gateway to creating an inclusive learning environment. The Journal of Economic Education, 31(1):30-43, 2000.

[50] Kurt Lewin. Dynamic Theory of Personality. McGraw-Hill Book Co, 1935. D. K. Adams and K. E. Zener, Trans.

[51] Barbara J. McNeil. A Meta-analysis of interactive video instruction: A 10 year review of achievement effects. $\mathrm{PhD}$ thesis, University of Idaho, 1989.

[52] J. Michael. Where's the evidence that active learning works? Advances in Physiology Education, 30(4): 159-167, 2006.

[53] MIT. MIT OpenCourseWare, 2012. URL http://ocw.mit.edu/about/our-history/.

[54] MIT. MIT office of the registrar, 2012. URL http://web.mit.edu/registrar/reg/costs/.

[55] M. Moravec, A. Williams, N. Aguilar-Roca, and D.K. O'Dowd. Learn before lecture: a strategy that improves learning outcomes in a large introductory biology class. CBE-Life Sciences Education, 9(4):473-481, 2010.

[56] National Center for Educational Statistics. Tuition costs of colleges and universities, 2012. Retrieved from https://nces.ed.gov/fastfacts/display.asp?id=76.

[57] Jeanne Ellis Ormrod. Educational psychology: Principles and applications. Merrill, 1995.

[58] C. Papadopoulos, A. Santiago-Román, and G. Portela. Work in progress: Developing and implementing an inverted classroom for engineering statics. In Frontiers in Education Conference (FIE), 2010 IEEE, pages F3F-1. IEEE, 2010.

[59] C. Papdopoulos and A. Santiago-Román. Implementing an inverted classroom model in engineering statics: Initial results. In Proceedings of the ASEE Annual Conference \& Exposition, Louisville, Kentucky, 2010.

[60] J. Piaget, D. Elkind, and A. Tenzer. Six psychological studies. Random House New York, 1967.

[61] M. Prince. Does active learning work? A review of the research. Jounal of Engeneering EducationWashington, 93:223-232, 2004.

[62] J. Rottier and B.J. Ogan. Cooperative learning in middle-level schools. NEA Professional Library, National Education Association, 1991.

[63] J. Sappington, K. Kinsey, and K. Munsayac. Two studies of reading compliance among college students. Teaching of Psychology, 29(4):272-274, 2002.

[64] Shlomo Sharan. Cooperative learning: Theory and research. Praeger Publishers, New York, 1990.

[65] R.E. Slavin. Synthesis of research of cooperative learning. Educational leadership, 48(5):71-82, 1991.

[66] B.L. Smith and J.T. MacGregor. What is collaborative learning? In M. Maher A.M. Goodsell and V. Tinto, editors, Collaborative learning: A sourcebook for higher education, pages 10-30. National Center on Postsecondary Teaching, Learning and Assessment, 1992.

[67] R.M. Stallman and L. Lessig. Free Software, Free Society: Selected Essays of Richard M. Stallman. Free Software Foundation, 2010. ISBN 9780983159209. URL http://books . google.com/books?id= Rv9HewAACAAJ.

[68] T. Stelzer, D.T. Brookes, G. Gladding, and J.P. Mestre. Impact of multimedia learning modules on an introductory course on electricity and magnetism. American Journal of Physics, 78:755, 2010. 
[69] Jeremy F. Strayer. The effects of the classroom flip on the learning environment: A comparison of learning activity in a traditional classroom and a flip classroom that used an intelligent tutoring system. $\mathrm{PhD}$ thesis, The Ohio State University, 2007.

[70] Robert Talbert. Learning MATLAB in the inverted classroom. In Proceedings of the ASEE Annual Conference \& Exposition, 2012.

[71] Elaine Tan and Nick Pearce. Open education videos in the classroom: Exploring the opportunities and barriers to the use of YouTube in teaching introductory sociology. Research in Learning Technology, 19(0), 2012. ISSN 2156-7077. URL http://www.researchinlearningtechnology . net/index.php/rlt/article/ view/7783.

[72] Jeffery S Thomas and Timothy A. Philpot. An inverted teaching model for a mechanics of materials course. In Proceedings of the ASEE Annual Conference \& Exposition, 2012.

[73] K.J. Topping and S.W. Ehly, editors. Peer-Assisted Learning. Lawrence Erlbaum Associates, 1998. ISBN 9780805825022. URL http://books . google.com/books?id=UZv6grfgeF4C.

[74] R. Toto and H. Nguyen. Flipping the work design in an industrial engineering course. In Frontiers in Education Conference, 2009. FIE 2009. 39th IEEE, pages 1-4. IEEE, 2009.

[75] J.R.H. Tudge and P.A. Winterhoff. Vygotsky, Piaget, and Bandura: Perspectives on the relations between the social world and cognitive development. Human Development, 36:61, 1993.

[76] Udacity. Udacity, 2012. URL http://www .udacity.com/udacity.

[77] Kurt VanLehn. The relative effectiveness of human tutoring, intelligent tutoring systems, and other tutoring systems. Educational Psychologist, 46(4):197-221, 2011.

[78] Matthew Alan Verleger. Analysis of an informed peer review matching algorithm and its impact on student work on model-eliciting activities. Dissertation, Purdue University, December 2009. URL http: $/ /$ proquest . umi. com/pqdlink?did=2056269091\&Fmt=7\&client Id=1652\&RQT=309\&VName=PQD.

[79] L.S. Vygotsky. Mind and society: The development of higher mental processes. Cambridge, MA: Harvard University Press, 1978.

[80] N. Warter-Perez and J. Dong. Flipping the classroom: How to embed inquiry and design projects into a digital engineering lecture. In Proceedings of the 2012 ASEE PSW Section Conference, 2012.

[81] Wikipedia. Wikipedia, 2012. URL http://en.wikipedia.org/wiki/Wikipedia.

[82] Sarah Zappe, Robert Lieicht, John Messner, Thomas Litzinger, and Hyeon Woo Lee. "Flipping" the classroom to explore active learning in a large undergraduate course. In Proceedings, American Society for Engineering Education Annual Conference \& Exposition, 2009.

[83] D. Zhang, L. Zhou, R.O. Briggs, and J.F. Nunamaker. Instructional video in e-learning: Assessing the impact of interactive video on learning effectiveness. Information \& Management, 43(1):15-27, 2006.

\section{References: Blog Posts \& News Articles on the Flipped Classroom}

(1) URL http://www. knewton.com/flipped-classroom/.

(2) URL http://www.npr.org/2012/12/07/166748835/more-teachers-flipping-the-school-dayupside-down.

(3) URL http://techcrunch.com/2012/05/09/move-over-harvard-and-mit-stanford-has-thereal-revolution-in-education/.

(4) URL http://electriceducator.blogspot.com/2010/09/flip-your-classroom-throughreverse.html.

(5) URL http://edudemic.com/2012/11/flipped-classrooms/.

(6) URL http://www .edutopia.org/blog/flip-stem-classroom-ainissa-ramirez.

(7) URL http://www .edutopia.org/blog/rethinking-the-flipped-classroom-idit-harelcaperton.

(8) URL http://www.edutopia.org/blog/film-festival-flipped-classroom. 
(9) URL http://www .edutopia.org/blog/flipped-classroom-pro-and-con-mary-beth-hertz.

(10) URL http://www .edutopia.org/blog/flipped-classroom-best-practices-andrew-miller.

(11) URL http://www.edutopia.org/blog/flipped-classroom-ramsey-musallam.

(12) URL http://www.telegraph.co.uk/finance/businessclub/7996379/Daniel-Pinks-ThinkTank-Flip-thinking-the-new-buzz-word-sweeping-the-US .html.

(13) URL http://www . thedailyriff .com/articles/how-the-flipped-classroom-is-radicallytransforming-learning-536.php.

(14) URL http://flippedclassroom.blogspot.com/.

(15) URL http://www.ascd.org/professional-development/webinars/flipped-classroomwebinars.aspx.

(16) URL http://usergeneratededucation.wordpress.com/2011/06/13/the-flipped-classroommodel-a-full-picture/.

(17) URL http://www. chron.com/news/houston-texas/houston/article/Flipped-classroomsturn-learning-around-3962085.php.

(18) URL http://blogs.kqed.org/mindshift/tag/flipped-classroom/.

(19) URL http://www.facultyfocus.com/articles/teaching-with-technology-articles/ understanding-the-flipped-classroom-part-1/.

(20) URL http://thejournal.com/articles/2012/10/01/bill-nye-the-science-guy-talksflipped-classrooms.aspx.

(21) URL http://www.dallasnews.com/news/education/headlines/20120927-flipped-classroomsin-north-texas-turn-traditional-teaching-on-its-head.ece.

(22) URL http://www.stanforddaily.com/2012/10/22/medical-school-experiments-withflipped-classroom-teaching-model/.

(23) URL http://hackeducation.com/2012/11/28/top-ed-tech-trends-of-2012-flippedclassroom/.

(24) URL http://gettingsmart.com/cms/blog/2012/12/how-the-flipped-classroom-turned-meinto-a-better-student/.

(25) URL http://www. waupacanow. com/communitynews/185460332.html.

(26) URL http://www.mlive.com/walker/index.ssf/2012/12/kenowa_hills_teacher_quickly_b. html.

(27) URL http://www.eschoolnews.com/2012/10/26/teachers-involve-parents-in-the-flippedclassroom-too/.

(28) URL http://www. edweek.org/ew/articles/2012/08/29/02el-flipped.h32.html.

(29) URL http: //edudemic.com/2012/11/16-examples-of-flipped-classrooms/.

(30) URL http: //plpnetwork.com/engage-with-the-flipped-classroom-the-full-picture/.

(31) URL http://plpnetwork.com/2011/07/25/the-flip-why-i-love-it-how-i-use-it/.

(32) URL http://storify.com/garystager/gary-stager-raises-questions-about-the-flippedcla.

(33) URL http://plpnetwork.com/2012/10/08/flip-love-affair/.

(34) URL http://www.huffingtonpost.com/mark-frydenberg/the-flipped-classroom-its_b_ 2300988.html.

(35) URL http://www.forbes.com/sites/pascalemmanuelgobry/2012/12/11/what-is-the-flippedclassroom-model-and-why-is-it-amazing-with-infographic/.

(36) URL http://www.deseretnews.com/article/765616415/Flipped-classrooms-Turninglearning-upside-down.html.

(37) URL http://www.kunc.org/post/classroom-flipping-two-colorado-teachers-perspectives.

(38) URL http://durham.patch.com/articles/board-of-education-discusses-the-flipped- 
classroom.

(39) URL http://stillwatergazette.com/2012/12/07/ties-conference-flips-over-isd-834flipped-classroom-idea/.

\section{References: Websites Dedicated to the Flipped Classroom}

-1- URL http://flippedclassroom.org/.

-2- URL http://flippedclassroom.com/.

-3- URL http://flipped-learning. com/.

-4- URL http://flippedhighschool.com/.

-5- URL http://www.techsmith.com/flipped-classroom.html.

\section{References: Web Resources for Flipped Classroom Teachers}

*1* URL http://www. showme.com/.

*2* URL http://www . educreations. com/.

*3* URL http://www. knowmia.com/.

*4* URL http://www. sophia.org/.

*5* URL http://www. sophia.org/flipped-classroom/flipped-classroom-certification.

*6* URL http://ed.ted.com/. 